\title{
Nutritional value of black and white oat cultivars ensiled in two phenological stages
}

\author{
Diego Bitencourt de David ${ }^{1}$, José Laerte Nörnberg ${ }^{1}$, Eduardo Bohrer de Azevedo ${ }^{1}$, Gilmar \\ Brüning $^{1}$, Julcemar Dias Kessler ${ }^{1}$, Fernando Reimann Skonieski ${ }^{1}$ \\ ${ }^{1}$ Departamento de Ciência e Tecnologia dos Alimentos, Universidade Federal de Santa Maria, Santa Maria, RS, Brasil.
}

ABSTRACT - It was evaluated in this work, crop yield, fermentative quality and nutritional value of the silage of cultivars of white (Avena Sativa L.) and black (Avena Strigosa Schreb) oats cut at two development stages. It was used an experimental randomized block design in a $4 \times 2$ factorial scheme, consisting of four oat cultivars (two cultivars of black oats: Aveia Preta Comum and UTFP 971; and two cultivars of white oats: ER 91156-1-2-1 and SI 98105-b), with four replicates. The cultivars were ensiled at flowering and dough grain stages. Oat cut at dough grain stage, especially genotypes from white oat, allows the obtainment of a more productive and qualitative silage. Cultivar, genotype, and maturation stage affect protein fractioning and oat silage carbohydrates.

Key Words: avena spp., carbohydrates, digestibility, fermentation, minerals, total digestible nutrients

\section{Valor nutricional de cultivares de aveia preta e branca ensiladas em dois estádios fenológicos}

\begin{abstract}
RESUMO - Avaliaram-se a produção das culturas, a qualidade fermentativa e o valor nutricional da silagem de cultivares de aveia-branca (Avena Sativa L.) e aveia-preta (Avena Strigosa Schreb) submetidas ao corte em dois estádios de maturação. O delineamento experimental foi de blocos ao acaso, num arranjo fatorial $4 \times 2$, composto por quatro cultivares de aveia (dois de aveia-preta: Comum e UTFP 971; e dois de aveia-branca: ER 91156-121 e SI 98105-b), com quatro repetições. Os cultivares foram ensilados nos estádios de floração e grão pastoso. O corte da aveia no estádio de grão pastoso, sobretudo dos genótipos de aveia-branca, possibilita obter silagem de maior qualidade, tanto produtiva quanto qualitativa. O cultivar, o genótipo e o estádio de maturação influenciam o fracionamento das proteínas e dos carboidratos de silagens de aveia.
\end{abstract}

Palavras-chave: avena spp., carboidratos, digestibilidade, fermentação, minerais, nutrientes digestíveis totais

\section{Introduction}

Ensilage of temperate grasses is an ancient technique routinely used in the northern hemisphere. In South America, these forages are more common in cooler regions, such as Argentina, southern Chile, and southern Brazil. However, only after the recent expansion of Brazilian agriculture, silage made with winter cereals began to receive attention from professionals and producers, and it started to be used in alternate crop systems and to utilize grain crops damaged by hail, frost, diseases, or/and pests (Mühlbach, 1999). In addition, an interesting alternative is to use these damaged crops for grazing or silage, and then the regrowth for grain production (Fontaneli et al., 2009). Among winter crops, oat is particularly important in southern Brazil, and it is planted on large areas in the states of Rio Grande do Sul, Santa Catarina and Paraná, because of its adaptation to the local climate and soils, to its productivity and flexibility when planted for grain, forage or soil cover purposes.

As described by Berto \& Mühlbach (1997), the optimal cutting point of oats for silage production is the vegetative stage, when their nutritional quality and digestibility are high. However, at that stage, oats also present high moisture level and buffering capacity, as well as low levels of soluble carbohydrates. In an attempt to solve these problems, some researchers (Primavesi et al., 2001; Boin et al., 2005) reassessed the optimal stage for cutting and/or treating this material before ensilage. Some alternatives, such as the use of bacterial inoculants, moisture absorption, and pre-wilting increase the production of lactic acid, promoting $\mathrm{pH}$ reduction. Nevertheless, these techniques 
have proven to be expensive, to have slow implementation, to produce inconsistent responses often, and they are subject to losses due to higher susceptibility of the forage to weather conditions and the difficulty of compacting the forage into the silo.

This study was conducted to evaluate the production, the fermentation quality and the nutritional value of silages produced with different cultivars of white and black oats at different growth stages.

\section{Material and Methods}

The experimental material was grown in an area that belongs to the sector of Nutrição Animal and Departmento de Zootecnia of the Universidade Federal de Santa Maria, state of Rio Grande do Sul, Brazil. The area is located at the center of the state of Rio Grande do Sul, $95 \mathrm{~m}$ altitude, $29^{\circ} 43^{\prime} \mathrm{S}$ and $53^{\circ} 42^{\prime} \mathrm{W}$. The soil is classified as Paleudalf and it belongs to the São Pedro mapping unit, with climate classified as Cfa (humid subtropical). Soil was fertilized with $250 \mathrm{~kg} / \mathrm{ha}$ of 5-20-20 NPK, with no N topdressing. Because the utilized area was part of a national study on oat cultivars for soil coverage, NPK fertilization and the absence of $\mathrm{N}$ topdressing were according to the guidelines of the Comissão Brasileira de Pesquisa em Aveia, regardless to soil analyses.

It was used a randomized block experimental design in a $4 \times 2$ factorial arrangement, consisting of four oat cultivars (two black oat cultivars: common oat and UTFP 971, and two white oat cultivars: ER 91156-121 and SI 98105-b), which hereafter will be referred as PC, UTFP, ER, and SI, respectively. Oats were cultivated in 5.0-m long and $1.0-\mathrm{m}$ wide plots, in five rows with $0.2 \mathrm{~m}$ row space, with two border rows. Each plot was considered an experimental unit, with four replicates each. Plants were cut at two different stages of maturity: flowering stage, when about $70 \%$ of the plants had flowered, and dough stage, when grains presented a soft texture. Flowering was characterized as the ratio between the total number of primary tillers (produced in the leaf axils of the main stem) in one hundred plants and the number of blooming primary tillers. Immediately after the green mass had been cut and weighed, the forage was chopped into approximately 2-cm particles, and they were manually ensiled using a small compactor in mini-silos made of PVC tubes $(60 \times 10 \mathrm{~cm})$. Silos were opened 50 days after ensiling, and analyzed at the Núcleo Integrado de Desenvolvimento de Análises Laboratoriais, Departamento de Tecnologia e
Ciência dos Alimentos (DTCA), Centro de Ciências Rurais (CCR), Universidade Federal de Santa Maria.

A fresh sample was collected from each silo for $\mathrm{pH}$ measurement (digital-pot DIGIMED), and another sample was used to extract the silage juice (Carver Press), in which ammonia nitrogen relative total nitrogen $\left(\mathrm{NH}_{3}-\mathrm{N} / \% \mathrm{TN}\right)$ was determined by distillation using magnesium oxide (AOAC, 1995). Another sample (of approximately $500 \mathrm{~g}$ ) was dried in a forced air ventilation oven $\left(55^{\circ} \mathrm{C}\right)$ and then weighed to calculate partial dry matter (PDM) and to estimate the yield per area. This sample was then ground in Wiley-type mill fitted with a 1-mm screen and submitted to dry matter (DM), mineral matter (MM), total nitrogen (TN), and ether extract (EE) determinations, according to AOAC (1995) procedures. Neutral detergent fiber (NDF) was determined according to Van Soest et al. (1991), with subsequent correction for ash and protein (NDFcp). The non-fiber carbohydrates (NFC) and total digestible nutrients (TDN) were estimated according to the NRC (2001) using the following equations: NFC $(\%)=100-(\mathrm{CP}+\mathrm{MM}+\mathrm{NDFcp}+$ EE) and $\mathrm{TDN}_{1 \mathrm{x}}=\mathrm{NFCtd}+\mathrm{CPtd}+(\mathrm{EE}-1) \times 2,25+\mathrm{NDFtd}-7$, in which TDN1x $(\%)=$ total digestible nutrients at maintenance intake; NFCtd = non-fiber carbohydrates truly digestible; CPtd = crude protein truly digestible; NDFtd $=$ neutral detergent fiber truly digestible and the value 7 refers to the constant of the metabolic fecal constituents. Organic matter in vitro digestibility (diet composition) was measured according to Tilley \& Terry (1963).

The following carbohydrate fractions were determined according to the methods proposed by Hall (2000): organic acids (OA), soluble carbohydrates (CHOsol), starch, soluble fiber (SF), hemicellulose (Hem), cellulose (Cel), and lignin (Lig). These fractions were grouped as: A (OA + CHOsol), $B_{1}$ (starch+SF), $B_{2}(\mathrm{Hem}+\mathrm{Cel})$ and $\mathrm{C}(\mathrm{Lig})$. Non-protein nitrogen (NPN), soluble nitrogen (SN), neutral detergent insoluble nitrogen (NDIN), and acid detergent insoluble nitrogen (ADIN) fractions were determined as described by Licitra et al. (1996) and they were used to fraction protein as it follows: A (NPN), $B_{1}(S N-N P N), B_{2}$ (100-A-B B $\left._{1}-\mathrm{B}_{3}-\mathrm{C}\right), \mathrm{B}_{3}$ (NDIN-ADIN) and C (ADIN). The mineral elements calcium (Ca), magnesium (Mg), phosphorus $(\mathrm{P})$, sodium $(\mathrm{Na})$, and potassium $(\mathrm{K})$ were analyzed as recommended by Tedesco et al. (1995).

Data were submitted to analysis of variance, and the means were compared by Tukey test at $5 \%$ probability of error. Orthogonal contrast analysis at $5 \%$ probability was performed as a complementary procedure. 


\section{Results and Discussion}

Dry matter yield (Table 1) was considerably high. Dough stage yield was $33.12 \%$ higher as compared to the flowering stage, which was similar to the findings reported by Bergen et al. (1991), who found 29\% higher dough stage yield as compared to milk stage. This high dry matter yield is probably related to the system of single cutting and to the advanced stage of maturity, allowing maximum leaf area index and, consequently, better photosynthetic interception. According to Dumont et al. (2005), the production of temperate forage grasses in vegetative stages is lower than that of plants at later stages of maturity, therefore, harvest can be delayed to obtain higher forage volume, despite of the reduced nutritional quality.

In terms of dry matter yield, an interaction $(\mathrm{P}<0.0004)$ among cultivars and maturity stages was obtained. ER cultivar stands out not only due to its good productivity, but also due to its production consistency among maturity stages. Cultivar SI presented the best yield in flowering stage, and PC in the dough stage.

There was no interaction $(\mathrm{P}>0.05)$ among stages of maturity and cultivars for the ratio of structural components of the plant. Flowering and dough stages presented similar ratios of stem (38.0,38.1\%), leaf decrease (39.3, 30.7\%) and panicle increase $(22.7,31.1 \%)$, respectively. In average, there was a $37 \%$ increase in the participation of the panicle in the dough grain as compared to the flowering stage. This increase may be explained by the advanced maturity of both phenological stages at harvest, since both leaf senescence and grain formation contributed to increase panicle percentage.

Dry matter (DM) and fermentation parameters ( $\mathrm{pH}$ and $\mathrm{NH}_{3}-\mathrm{N} / \% \mathrm{TN}$ ) were affected by the interaction between cultivar and maturity stage, indicating that fermentation depends on plant cultivar and maturity stage at the time of cutting for ensiling. Dry matter content shows that cultivars at flowering stage presented higher moisture content, which declined as they matured to dough grain stage. According to Haigh (1999), who evaluated effluent production by temperate grass silages in conventional silos, found that $25 \%$ DM content is sufficient to reduce effluent production, and suggests that silages with $30 \%$ DM content have the lowest risk to produce effluent and undesirable fermentation (Harrison et al., 1994). In the flowering stage, only SI cultivar presented DM content higher than $30 \%$, whereas in the dough stage, only UTFP cultivar had less than $30 \%$ DM. This difference may be explained by structural component

Table 1 - Dry matter yield, ratio of structural components, dry matter and fermentation quality of the silage of oats cut at the flowering or dough grain stages

\begin{tabular}{|c|c|c|c|c|c|c|c|}
\hline \multirow[t]{2}{*}{ Stage } & \multicolumn{6}{|c|}{ Cultivar } & \multirow[t]{2}{*}{$\mathrm{P}>\mathrm{F}^{2}$} \\
\hline & PC & UTFP & ER & SI & Average & $\mathrm{CV}^{1}$ & \\
\hline & \multicolumn{6}{|c|}{ Dry matter yield (kg/ha) } & \\
\hline Flowering & $5479 a b$ & $3547 b$ & $6746 a$ & $7079 a$ & 5712 & 17.3 & $<0,01$ \\
\hline \multirow[t]{2}{*}{ Dough grain } & $9166 a$ & $7907 a b$ & $9.170 \mathrm{a}$ & $4174 b$ & 7604 & 19.0 & \\
\hline & \multicolumn{6}{|c|}{ Stem (\%DM) } & \\
\hline Flowering & 41.4 & 36.1 & 36.2 & 38.1 & 38.0 & 7.1 & 0.05 \\
\hline \multirow[t]{2}{*}{ Dough grain } & 44.0 & 39.8 & 36.2 & 32.6 & 38.1 & 7.4 & \\
\hline & \multicolumn{6}{|c|}{ Leaves (\%DM) } & \\
\hline Flowering & 38.2 & 44.4 & 37.0 & 37.8 & $39.3 \mathrm{~A}$ & 7.1 & 0.06 \\
\hline \multirow[t]{2}{*}{ Dough grain } & 27.9 & 31.3 & 28.1 & 35.7 & $30.7 \mathrm{~B}$ & 12.9 & \\
\hline & \multicolumn{6}{|c|}{ Panicle (\%DM) } & \\
\hline Flowering & 20.4 & 19.5 & 26.8 & 24.2 & $22.7 \mathrm{~B}$ & 2.3 & 0.64 \\
\hline \multirow[t]{2}{*}{ Dough grain } & 28.1 & 29.0 & 35.7 & 31.7 & $31.1 \mathrm{~A}$ & 6.6 & \\
\hline & \multicolumn{6}{|c|}{ Dry matter (\%) } & \\
\hline Flowering & $24.0 \mathrm{~b}$ & $21.3 c$ & $26.6 b$ & $34.3 a$ & 26.6 & 4.7 & $<0.01$ \\
\hline \multirow[t]{2}{*}{ Dough grain } & $31.3 b$ & $27.2 \mathrm{c}$ & 33.6ab & $35.6 a$ & 31.9 & 4.4 & \\
\hline & \multicolumn{6}{|c|}{$\mathrm{pH}$} & \\
\hline Flowering & $4.70 \mathrm{ab}$ & $4.77 \mathrm{a}$ & $3.56 b$ & 4.53ab & 4.39 & 3.56 & $<0.01$ \\
\hline \multirow[t]{2}{*}{ Dough grain } & 3.77 & 3.80 & 3.80 & 3.67 & 3.76 & 3.94 & \\
\hline & \multicolumn{6}{|c|}{$\mathrm{N}-\mathrm{NH}_{3}(\% \mathrm{TN})$} & \\
\hline Flowering & $4.4 \mathrm{~b}$ & $9.1 \mathrm{a}$ & $2.3 c$ & $2.8 \mathrm{cb}$ & 4.6 & 13.5 & $<0.01$ \\
\hline Dough grain & 2.8 & 2.3 & 2.9 & 1.7 & 2.4 & 21.8 & \\
\hline
\end{tabular}

Means with different small letters in the same row are different by Tukey test at 5\%.

Means with different capital letters in the same column are different by Tukey test at $5 \%$.

${ }^{1} \mathrm{CV}(\%)=$ coefficient of variation.

${ }^{2}$ Probability of error of the interaction between stages of maturity and cultivars. 
ratios at the different stages of maturity, because the panicle and the stem contribute to increase DM content, while cultivars with higher leaf persistence and fewer stems may not achieve the optimal DM content for ensiling. Moreover, the high $\mathrm{pH}$ values obtained in the floweringstage silages may be attributed to their low DM content, whereas all dough-stage cultivars presented optimal $\mathrm{pH}$ range, which, according to McDonald et al. (1991), varies from 3.6 to 4.2. All cultivars in both stages of maturity showed $\mathrm{NH}_{3}-\mathrm{N} / \%$ TN values within the range described as normal for good quality silages, i.e., from 0 to $12.5 \%$ (Lavezzo \& Andrade, 1994).

Flowering-stage silages presented higher crude protein content (Table 2) as compared to those at dough stage. Average crude protein content of the two developmental stages was $7.19 \%$, which is lower than the value of $12.9 \%$ crude protein for oat silage found in the NRC tables (2001). The absence of topdressing with nitrogen and the advanced stage of maturity at the time of ensiling may have significantly contributed for these relatively low CP levels. These results may have different interpretations. The low silage CP content can be considered either an economic loss because of the need for adding protein supplements to balance the diet, or, when organic acids and inorganic ions are taken into account, this low CP level may contribute to reduce silage buffering capacity, promoting a faster $\mathrm{pH}$ drop, and consequently lower breakdown of other nutritional components of the silage (Cherney \& Cherney, 2003).

The interaction between stages of maturity and cultivars significantly influenced $(\mathrm{P}<0.0021)$ ether extract, whose values ranged from 1.7 to $2.7 \%$, and were lower than $3.4 \%$ in the dough stage.

There was no effect of the interaction between stages of maturity and cultivars on NDFcp and NFC $(\mathrm{P}<0.69$ and $\mathrm{P}<0.09$ ), respectively. The content of NDFcp ranged from 65.1 to $71.1 \%$, which is higher than that described by the NRC (2001), with an average of $60.6 \%$ for oat silage in dough stage. However, our findings are consistent with those described by Boin et al. (2005), with 66.8 and $63.7 \%$ for oat silages produced at the early flowering and dough stages, respectively. The non-fibrous carbohydrates (NFC) correspond to the fraction of highly digestible carbohydrates, such as mono- and oligosaccharides, and neutral detergent soluble polysaccharides (starch, pectin, etc.). Non fibrous carbohydrates content was higher in silages made of oats at the dough stage when compared to the flowering stage, probably due to the higher starch accumulation during the later stages of grain filling.

The interaction between maturity stages and cultivars significantly influenced $(\mathrm{P}<0.01)$ IVOMD. The best results were obtained in ER cultivars (74.4\%) and SI (72.5\%) cultivars

Table 2 - Nutritional quality (\% of dry matter) of oat silage in the flowering and dough grain stages

\begin{tabular}{|c|c|c|c|c|c|c|c|}
\hline \multirow[t]{2}{*}{ Stage } & \multicolumn{6}{|c|}{ Cultivar } & \multirow[t]{2}{*}{$\mathrm{P}>\mathrm{F}^{2}$} \\
\hline & PC & UTFP & ER & SI & Average & $\mathrm{CV}^{1}$ & \\
\hline \multicolumn{8}{|c|}{ Crude protein $(\mathrm{CP})$} \\
\hline Flowering & 8.7 & 9.8 & 6.4 & 6.5 & $7.9 \mathrm{~A}$ & 10.1 & 0.07 \\
\hline Dough grain & 6.6 & 7.5 & 6.1 & 5.9 & $6.5 \mathrm{~B}$ & 11.3 & \\
\hline \multicolumn{8}{|c|}{ Ether extract (EE) } \\
\hline Flowering & $2.4 \mathrm{ab}$ & $2.1 \mathrm{ab}$ & $2.0 \mathrm{~b}$ & $2.7 \mathrm{a}$ & 2.3 & 10.6 & $<0.01$ \\
\hline Dough grain & 1.7 & 2.2 & 2.6 & 2.0 & 2.1 & 14.7 & \\
\hline \multicolumn{8}{|c|}{ Neutral detergent fiber corrected for ash and crude protein (NDFcp) } \\
\hline Flowering & 71.1 & 67.7 & 65.9 & 71.0 & 68.9 & 4.4 & 0.69 \\
\hline Dough grain & 67.8 & 67.7 & 65.1 & 68.3 & 67.2 & 4.0 & \\
\hline \multicolumn{8}{|c|}{ Non-fiber carbohydrates (NFC) } \\
\hline Flowering & 8.9 & 10.7 & 17.6 & 13.5 & $12.7 \mathrm{~B}$ & 20.5 & 0.09 \\
\hline Dough grain & 17.0 & 15.5 & 18.9 & 17.0 & $17.1 \mathrm{~A}$ & 14.3 & \\
\hline \multicolumn{8}{|c|}{ In vitro organic matter digestibility (IVOMD) } \\
\hline Flowering & $60.1 b$ & $69.4 \mathrm{a}$ & $74.4 \mathrm{a}$ & 59.9b & 65.9 & 4.3 & $<0.01$ \\
\hline Dough grain & $62.8 b$ & $67.6 \mathrm{ab}$ & $65.9 \mathrm{ab}$ & $72.5 a$ & 67.2 & 4.1 & \\
\hline \multicolumn{8}{|c|}{ Total digestible nutrients (TDN) } \\
\hline Flowering & 52.5 & 54.6 & 55.5 & 52.4 & $53.7 \mathrm{~B}$ & 3.4 & 0.17 \\
\hline Dough grain & 55.0 & 56.5 & 55.9 & 57.7 & $56.3 \mathrm{~A}$ & 2.9 & \\
\hline
\end{tabular}

Means with different small letters in the same row are different by Tukey test at $5 \%$.

Means with different capital letters in the same column are different by Tukey test at $5 \%$.

${ }^{1} \mathrm{CV}(\%)=$ coefficient of variation.

2 Probability of error of the interaction between stages of maturity and cultivars. 
at the flowering and dough stages, respectively. Average values from 65.9 to $67.2 \%$ were determined for flowering and dough stages, respectively. These values are similar to those described by Dumont et al. (2005) for silages made of oats at intermediate stage of maturity (71.1\%) and higher than those found by Boin et al. (2005) for white oat silage, which ranged from 58.3 at the beginning of flowering stage to $48.4 \%$ at the hard dough stage.

Total digestible nutrients increased $(\mathrm{P}<0.05)$ as the plants matured, presenting values close to that of the NRC (1996), 56.8\%, and to those reported by Boin et al. (2005), from 49.9 to $56.1 \%$ at different stages of maturity. Considering that TDN includes the digestibility of its fractions (NDF, NFC, CP, and EE), this increase may be explained by the increasing levels of non-fibrous carbohydrates as the plant matures, probably due to the accumulation of starch in the grain.

The quality characteristics (Table 3) of white oat genotypes indicate that these are more suitable for silage production than black oat cultivars, as shown by the higher ratio of panicles $(\mathrm{P}<0.01)$ and higher organic matter digestibility $(\mathrm{P}=0.04)$ in white oats, which are two essential characteristics of high quality silages.

According to McDonald et al. (1991), about 30\% of forage protein or total nitrogen may change its fractions according to the ensiling process, and therefore, the study of silage fractions allows determining protein quality after the fermentation process, thereby contributing to a more accurate diet formulation. The analysis of the crude protein fractions (Table 4) showed higher participation of the A

Table 3 - Contrast analysis of dry matter yield, phenology, fermentative and nutritional characteristics of different oat genotypes cut at the flowering and dough grain stages for silage production

\begin{tabular}{|c|c|c|c|}
\hline Item & Black oats & White oats & $\mathrm{P}>\mathrm{F}$ \\
\hline Dry matter yield (kg/ha) & 6254 & 6792 & 0.06 \\
\hline Stem $(\%)$ & 40.3 & 35.8 & $<0.01$ \\
\hline Leaf (\%) & 35.4 & 34.6 & 0.35 \\
\hline Dry matter $(\%)$ & 25.9 & 32.5 & $<0.01$ \\
\hline $\mathrm{pH}$ & 4.36 & 3.89 & 0.58 \\
\hline $\mathrm{N}-\mathrm{NH}_{3} \% / \mathrm{TN}$ & 4.6 & 2.4 & 0.47 \\
\hline Neutral detergent fiber corrected for ash and crude protein (\%DM) & 68.4 & 67.6 & 0.51 \\
\hline Non fibrous carbohydrates (\%DM) & 13.0 & 16.7 & 0.18 \\
\hline In vitro organic matter digestibility (\%DM) & 65.0 & 68.2 & 0.04 \\
\hline Total digestible nutrients (\%DM) & 54.6 & 55.4 & 0.30 \\
\hline
\end{tabular}

Table $4-A, B_{1}, B_{2}, B_{3}$ and $C$ nitrogen fractions (as \% of crude protein) in the silages of oats cut at the flowering and dough grain stag

\begin{tabular}{|c|c|c|c|c|c|c|c|}
\hline \multirow[t]{2}{*}{ Stage } & \multicolumn{6}{|c|}{ Cultivar } & \multirow[t]{2}{*}{$\mathrm{P}>\mathrm{F}^{2}$} \\
\hline & $\mathrm{PC}$ & UTFP & ER & SI & Average & $\mathrm{CV}^{1}$ & \\
\hline & \multicolumn{6}{|c|}{$\mathrm{A}(\% \mathrm{CP})$} & \\
\hline Flowering & $63.9 a$ & $57.6 \mathrm{~b}$ & $56.4 \mathrm{~b}$ & $50.1 \mathrm{c}$ & 57.0 & 3.2 & $<0.01$ \\
\hline \multirow[t]{2}{*}{ Dough grain } & 55.4 & 59.4 & 57.0 & 56.6 & 57.1 & 5.3 & \\
\hline & \multicolumn{6}{|c|}{$\mathrm{B}_{1}(\% \mathrm{CP})$} & \\
\hline Flowering & $19.0 \mathrm{c}$ & $24.4 \mathrm{~b}$ & $22.3 \mathrm{~b}$ & $30.8 a$ & 24.1 & 3.7 & $<0.01$ \\
\hline \multirow[t]{2}{*}{ Dough grain } & $17.1 \mathrm{a}$ & $9.9 \mathrm{~d}$ & $13.2 \mathrm{c}$ & $15.1 \mathrm{~b}$ & 13.8 & 1.6 & \\
\hline & \multicolumn{6}{|c|}{$\mathrm{B}_{2}(\% \mathrm{CP})$} & \\
\hline Flowering & 8.8 & 9.9 & 13.5 & 7.1 & 9.8 & 26.6 & 0.02 \\
\hline \multirow[t]{2}{*}{ Dough grain } & 15.7 & 15.9 & 12.9 & 16.8 & 15.3 & 15.4 & \\
\hline & \multicolumn{6}{|c|}{$\mathrm{B}_{3}(\% \mathrm{CP})$} & \\
\hline Flowering & $2.7 \mathrm{~b}$ & $3.1 \mathrm{~b}$ & $4.2 \mathrm{~b}$ & $7.7 \mathrm{a}$ & 4.4 & 26.3 & $<0.01$ \\
\hline \multirow[t]{2}{*}{ Dough grain } & $4.4 \mathrm{ab}$ & $9.0 \mathrm{a}$ & $9.0 \mathrm{a}$ & $3.6 \mathrm{~b}$ & 6.5 & 25.6 & \\
\hline & \multicolumn{6}{|c|}{ C $(\% \mathrm{CP})$} & \\
\hline Flowering & 6.9 & 5.3 & 7.4 & 7.3 & 6.7 & 17.1 & 0.75 \\
\hline Dough grain & 7.8 & 7.0 & 7.9 & 7.7 & 7.6 & 16.2 & \\
\hline
\end{tabular}

Means with different small letters in the same row are different by Tukey test at $5 \%$;

${ }^{1} \mathrm{CV}(\%)=$ coefficient of variation.

2 Probability of error of the interaction among stages of maturity and cultivars. 
fraction as compared to the other fractions. The A fraction consists of non-protein nitrogen and it is highly degradable in the rumen.

A fraction accounted for $63.9 \%$ of crude protein in PC cultivar at the flowering stage, and for 57.6, 56.4 and 50.1\% in UTFP, ER and SI cultivars, respectively. High concentrations of this fraction were also obtained at the dough stage, but the variation among cultivars was much lower. NRC (2001) describes a lower value, $45.6 \%$ for oat silage, than those obtained in the present study. Silages with high soluble protein content may result in high ruminal ammonia concentrations, and under certain feeding situations, it may cause moderate ammonia poisoning and a consequent reduction of intake (Charmley, 2000). Although it may not be the case with the protein levels determined at maturity stages evaluated in the present study, the high protein levels in oats cut at earlier stages need to be considered.

$\mathrm{B}$ fraction represents the true protein, but it is divided in three fractions, based on ruminal degradation rate. B1 fraction is considered true protein with fast and complete ruminal degradation (albumin and some globulins). At the flowering stage, SI cultivar presented the highest $\mathrm{B}_{1}$ fraction content and PC cultivar, the lowest (30.8 and $19.0 \%$, respectively). However, at the dough stage, the highest value was observed in PC cultivar, with values of 17.1, 15.1, 13.2, and 9.9\% for the PC, SI, ER and UTFP cultivars, respectively. Moreover, this fraction was influenced by the interaction between cultivars and maturity stages. The $\mathrm{B}_{2}$ fraction has an intermediate degradation rate; however, this rate may vary, particularly because its composition is determined by the difference from the other protein fractions. Silages made with dough-stage plants presented higher $\mathrm{B}_{2}$ fraction compared to those produced with flowering-stage forages, with 15.3 and $9.8 \%$ respectively. As shown by the results from $B_{1}$ and $B_{2}$ fraction, protein rumen degradation rate was reduced as the plants matured from the flowering stage to the dough stage. $\mathrm{B}_{3}$ fraction, which is usually associated with the cell wall, includes extensins, prolamins, and denatured proteins, therefore it has slow rumen degradation rate. Interaction between cultivars and developmental stages affected $B_{3}$ fraction. At the flowering stage, this fraction was higher in the SI cultivar than in other cultivars, whereas at the dough stage, it contained lower $\mathrm{B}_{3}$ levels as compared to the others, except for the PC cultivar (Table 4). According to NRC (2001), B fraction $\left(B_{1}+B_{2}+B_{3}\right)$ values of oat silage are around $30.9 \%$ thus, below those obtained in the present experiment, in which the average was $37 \%$. Finally, the C fraction, which is acid detergent insoluble, indigestible, and associated with lignin, was not different $(\mathrm{P}>0.05)$ among cultivars or stages of maturity. This supports the assertion that protein bound to fiber and unavailable protein levels do not change as the plant matures.

Organic acid composition was not different $(\mathrm{P}>0.05)$ among cultivars, but it increased at the dough grain stage in relation to the flowering stage (Table 5). The levels of soluble carbohydrates and mono- and oligosaccharides with fast rumen degradation were higher $(\mathrm{P}<0.05)$ in the ER cultivar at flowering stage, which may reflect a higher initial content of these compounds in the fresh material, and helps to explain the adequate fermentation of this cultivar, despite of presenting DM content below 30\% (Table 1). The results, except for ER, are similar to the value of $1.67 \%$ suggested by Valadares et al. (2002) for oat silage.

$\mathrm{B}_{1}$ fraction consists of soluble fiber and starch that are constituents of the cellular content and of the middle lamella, and it presents intermediate degradation. The results show that, at dough stage, white oats had higher levels of starch in relation to black oats, possibly reflecting the better nutritional composition of white oat grains.

$\mathrm{B}_{2}$ fraction, which includes hemicellulose and cellulose and it is slow degradated in the rumen, was not different among cultivars. Despite being significantly different among cultivars at both stages of maturity, $\mathrm{C}$ fraction variation was very close to the average (5.8\% at flowering and 5.3\% at dough stages), and it was also characterized by relatively low values, similar to that found by Boin et al. (2005), 5.7\% for oat silage cut at the beginning of the flowering stage.

By using the analysis of contrasts (Table 6), average protein and carbohydrate fractions of white and black oat silages were compared. Among the protein fractions, only $\mathrm{B}_{1}$ fraction differed significantly $(\mathrm{P}<0.05)$ among genotypes, with the highest values obtained for the white oat silages.

Soluble carbohydrates, soluble fiber, and starch contents were higher in white oat genotypes, probably due to their better grain development. The value of the $B_{2}$ fraction observed in the present study was lower (49.2\%), and the $\mathrm{C}$ fraction was higher (18\%) than the average values reported by Zeoula et al. (2003).

Mineral content values were not different among cultivars or maturity stages (Table 7 ). In the review by Minson (1990), the average concentration of phosphorus in samples of 1,823 forages collected around the world and described in international literature was $0.29 \%$ higher than that found in the present study. Calcium levels ranged from $0.27 \%$ to $0.42 \%$, decreasing as plants matured.

The levels of potassium found in UTFP were higher $(\mathrm{P}<0.05)$ than in the other genotypes at both stages of maturity. Magnesium levels, however, ranged from $0.11 \%$ 
Table 5 - Soluble carbohydrates, organic acids, soluble fiber, starch, cellulose and hemicellulose fractions of total carbohydrates $\left(A, B_{1}, B_{2}\right.$, and $\left.C\right)$ as a percentage of dry matter in silages of oats cut at the flowering and dough grain stages

\begin{tabular}{|c|c|c|c|c|c|c|c|}
\hline Stage & \multicolumn{6}{|c|}{ Cultivar } & $\mathrm{P}>\mathrm{F}^{2}$ \\
\hline \multicolumn{8}{|c|}{ Soluble carbohydrates } \\
\hline Flowering & $1.6 b$ & $1.6 \mathrm{~b}$ & $4.1 \mathrm{a}$ & $1.3 \mathrm{~b}$ & 2.2 & 7.0 & \multirow[t]{2}{*}{$<0.01$} \\
\hline \multirow[t]{2}{*}{ Dough grain } & $3.1 \mathrm{~b}$ & $2.8 \mathrm{~b}$ & $3.0 \mathrm{~b}$ & $5.1 \mathrm{a}$ & 3.5 & 19.2 & \\
\hline & \multicolumn{6}{|c|}{ Organic acids } & \\
\hline Dough grain & \multicolumn{6}{|c|}{ Fraction A (total) } & \multirow{3}{*}{$<0.01$} \\
\hline Flowering & $4.9 \mathrm{~b}$ & $6.2 \mathrm{~b}$ & $10.4 \mathrm{a}$ & $4.3 b$ & 6.5 & 22.6 & \\
\hline \multirow[t]{2}{*}{ Dough grain } & 10.5 & 9.0 & 10.2 & 11.1 & 10.2 & 17.1 & \\
\hline & \multicolumn{6}{|c|}{ Soluble fiber } & \multirow[b]{2}{*}{$<0.01$} \\
\hline Flowering & $2.3 \mathrm{~b}$ & $2.2 \mathrm{~b}$ & $3.2 \mathrm{ab}$ & $5.5 \mathrm{a}$ & 3.3 & 28.6 & \\
\hline Dough grain & \multicolumn{6}{|c|}{ Fraction $\mathrm{B}_{1}$ (total) } & \multirow{3}{*}{0.03} \\
\hline Flowering & $4.0 \mathrm{c}$ & $4.5 \mathrm{bc}$ & $7.2 \mathrm{ab}$ & $8.0 \mathrm{a}$ & 5.9 & 16.0 & \\
\hline \multirow[t]{2}{*}{ Dough grain } & 6.6 & 6.5 & 8.6 & 6.7 & 7.1 & 18.6 & \\
\hline & \multicolumn{6}{|c|}{ Hemicellulose } & \multirow{3}{*}{0.96} \\
\hline Flowering & 24.6 & 23.9 & 24.4 & 27.4 & 25.1 & 9.2 & \\
\hline \multirow[t]{2}{*}{ Dough grain } & 24.3 & 23.7 & 23.2 & 27.1 & 24.6 & 6.3 & \\
\hline & \multicolumn{6}{|c|}{ Cellulose } & \multirow{3}{*}{0.28} \\
\hline Flowering & 40.9 & 39.4 & 36.3 & 36.6 & 38.3 & 2.7 & \\
\hline \multirow[t]{2}{*}{ Dough grain } & 38.1 & 39.5 & 35.9 & 36.7 & 37.5 & 4.5 & \\
\hline & \multicolumn{6}{|c|}{ Fraction $\mathrm{B}_{2}$ (total) } & 0.80 \\
\hline
\end{tabular}

Means with different small letters in the same row are different by Tukey test at $5 \%$.

Means with different capital letters in the same column are different by Tukey test at $5 \%$.

${ }^{1} \mathrm{CV}(\%)$ = coefficient of variation.

${ }^{2}$ Probability of error of the interaction between stages of maturity and cultivars.

Table 6 - Analysis of contrasts between protein and carbohydrate fractions of silages of oats cut at the flowering and dough grain stages

\begin{tabular}{|c|c|c|c|c|}
\hline \multicolumn{2}{|c|}{ Item } & Black oat & White oat & $\mathrm{P}>\mathrm{F}$ \\
\hline \multicolumn{5}{|c|}{ Protein fraction (\% of crude protein) } \\
\hline \multicolumn{2}{|c|}{ A } & 59.1 & 55.0 & 0.73 \\
\hline \multicolumn{2}{|l|}{$\mathrm{B}_{1}$} & 17.6 & 20.3 & $<0.01$ \\
\hline \multicolumn{2}{|l|}{$\mathrm{B}_{2}$} & 12.6 & 12.6 & 0.51 \\
\hline \multicolumn{2}{|l|}{$\mathrm{B}_{3}$} & 4.8 & 6.1 & 0.68 \\
\hline \multicolumn{2}{|l|}{$\mathrm{C}^{3}$} & 6.8 & 7.6 & 0.59 \\
\hline \multicolumn{5}{|c|}{ Carbohydrates fraction (\% of dry matter) } \\
\hline & Soluble carbohydrates & 2.3 & 3.4 & 0.03 \\
\hline & Organic acids & 5.4 & 5.6 & 0.86 \\
\hline & Total & 7.6 & 9.0 & 0.39 \\
\hline & Soluble fiber & 3.3 & 3.3 & $<0.01$ \\
\hline & Starch & 2.1 & 4.4 & $<0.01$ \\
\hline & Total & 5.4 & 7.6 & 0.18 \\
\hline \multirow[t]{3}{*}{$\mathrm{B}_{2}$} & Hemicellulose & 24.1 & 25.5 & 0.24 \\
\hline & Cellulose & 39.5 & 36.4 & 0.04 \\
\hline & Total & 63.6 & 61.9 & 0.37 \\
\hline \multicolumn{2}{|l|}{$\mathrm{C}$} & 5.3 & 5.7 & 0.45 \\
\hline
\end{tabular}


to $0.18 \%$, with similar averages among stages of maturity. Mayland et al. (1976) estimated the risk of tetany posed by various forages, and observed a higher risk in wheat and oats, followed by barley and rye. Therefore, cultivars with high magnesium levels may be used as alternatives in areas with deficiency of this mineral; however, this does not preclude the need of an adequate mineral supplementation. Sodium concentrations varied from 0.02 to $0.16 \% \mathrm{DM}$, which are consistent with the study by McDowell \& Valle (2006), who found that most forages present sodium levels in the range 0.007 to $0.12 \% \mathrm{DM}$.

The obtained contents of ashes and other macro minerals were below those reported by the NRC (2001), which reports values of $9.8 \%$ ash, $0.31 \%$ phosphorus, $2.89 \%$ potassium, $0.20 \%$ magnesium, $0.24 \%$ sodium, and $0.52 \%$ calcium, as well as those found in Brazilian feed tables (Valadares et al., 2002), which mention only phosphorus (0.40\%) and calcium $(0.50 \%)$ for oat silage.

Table 7 - Mineral composition of silages of oats cut at the flowering and dough grain stages, as a percentage of dry matter

\begin{tabular}{|c|c|c|c|c|c|c|}
\hline \multirow[t]{2}{*}{ Stage } & \multicolumn{6}{|c|}{ Cultivar } \\
\hline & PC & UTFP & ER & SI & Average & $\mathrm{CV}^{1}$ \\
\hline & \multicolumn{6}{|c|}{ Mineral matter } \\
\hline Flowering & 8.9 & 9.7 & 8.1 & 7.5 & 8.5 & 7.00 \\
\hline \multirow[t]{2}{*}{ Dough grain } & 6.9 & 7.1 & 7.4 & 6.8 & 7.1 & 10.67 \\
\hline & \multicolumn{6}{|c|}{ Phosphorus } \\
\hline Flowering & $0.17 \mathrm{~b}$ & $0.26 \mathrm{a}$ & $0.19 \mathrm{ab}$ & $0.21 \mathrm{ab}$ & $0.21 \mathrm{~B}$ & 14.36 \\
\hline \multirow[t]{2}{*}{ Dough grain } & $0.21 \mathrm{a}$ & $0.25 a$ & $0.22 \mathrm{a}$ & $0.27 a$ & $0.23 \mathrm{~A}$ & 10.69 \\
\hline & \multicolumn{6}{|c|}{ Calcium } \\
\hline Flowering & $0.42 \mathrm{ab}$ & $0.48 a$ & $0.31 \mathrm{ab}$ & $0.24 b$ & $0.36 \mathrm{~A}$ & 22.77 \\
\hline \multirow[t]{2}{*}{ Dough grain } & $0.34 \mathrm{a}$ & $0.38 \mathrm{a}$ & $0.27 \mathrm{~b}$ & $0.27 b$ & $0.32 \mathrm{~B}$ & 7.10 \\
\hline & \multicolumn{6}{|c|}{ Potassium } \\
\hline Flowering & $1.65 b$ & $2.64 \mathrm{a}$ & $1.91 \mathrm{~b}$ & $1.59 b$ & $1.95 \mathrm{~A}$ & 7.96 \\
\hline \multirow[t]{2}{*}{ Dough grain } & $1.44 \mathrm{~b}$ & $2.00 \mathrm{a}$ & $1.69 \mathrm{~b}$ & $1.51 \mathrm{~b}$ & $1.66 \mathrm{~B}$ & 6.33 \\
\hline & \multicolumn{6}{|c|}{ Magnesium } \\
\hline Flowering & $0.11 b$ & $0.18 \mathrm{a}$ & $0.14 a b$ & $0.13 a b$ & $0.14 \mathrm{~A}$ & 15.93 \\
\hline \multirow[t]{2}{*}{ Dough grain } & $0.12 \mathrm{a}$ & $0.13 a$ & $0.14 \mathrm{a}$ & $0.13 a$ & $0.13 \mathrm{~B}$ & 15.27 \\
\hline & \multicolumn{6}{|c|}{ Sodium } \\
\hline Flowering & $0.16 a$ & $0.12 \mathrm{ab}$ & $0.02 c$ & $0.05 b c$ & $0.09 \mathrm{~A}$ & 30.65 \\
\hline Dough grain & $0.10 \mathrm{a}$ & $0.08 \mathrm{ab}$ & $0.02 \mathrm{c}$ & $0.07 \mathrm{~b}$ & $0.06 \mathrm{~B}$ & 13.68 \\
\hline
\end{tabular}

Means with different small letters in the same row are different by Tukey test at $5 \%$.

Means with different capital letters in the same column are different by Tukey test at $5 \%$.

${ }^{1} \mathrm{CV}(\%)=$ coefficient of variation.

According to the mineral requirement tables for various ruminant species described by McDowell and Valle (2006), the critical levels of phosphorus, calcium, potassium, magnesium, and sodium are $0.25,0.3,0.7,0.2$, and $0.06 \%$ on dry matter basis, respectively. Therefore, phosphorus and magnesium levels determined in the present study are below the critical levels if ruminants are fed exclusively oat silage.

\section{Conclusions}

The silage of oats cut at the dough grain stage presents higher yield, better fermentation quality, and higher nutritional value as compared to the silage produced with oats cut at the flowering stage. White oat cultivars produce better silages than black oat cultivars. The ER cultivar presents the best balance of the studied parameters at both stages of maturity.

\section{References}

ASSOCIATION OF OFFICIAL ANALITICAL CHEMISTRY AOAC. Official methods of analysis. 16.ed. Arlington: AOAC International, 1995. 1025p.

BERGEN W.G.; BYREM, T.M.; GRANT, A.L. Ensiling characteristics of whole-crop small grains harvested at milk and dough stages. Journal of Animal Science, v.69, p.1766-1774, 1991.

BERTO, J.L.; MÜHLBACH, P.R.F. Silagem de aveia preta no estádio vegetativo, submetida à ação de inoculantes e ao efeito do emurchecimento. Revista Brasileira de Zootecnia, v.26, n.2, p.651-658, 1997.

BOIN, C.; FLOSS, E.L.; CARVALHO, M.P. et al. Composição e digestibilidade de silagens de aveia branca produzidas em quatro estádios de maturação. Boletim de Industria Animal, v.62, n.1, p.35-43, 2005

CHARMLEY, E. Towards improved silage quality - A review. Winnipeg, Manitoba, Forage Ruminant Workshop, 2000.

CHERNEY, J.H.; CHERNEY, D.J.R. Assessing silage quality. In: BUXTON, D.R.; MUCK, R.E.; HARRISON, J.H. (Eds.) Silage science and technology. Madison, 2003. p.141-198. 
DUMONT, J.C.; ANRIQUE, R.; ALOMAR, D. Efecto de dos sistemas de determinácion de matéria seca en la composición química y calida del ensilaje directo de avena en diferentes estados fenológicos. Agricultura Técnica, v.65, n.4, p.388-396, 2005.

FONTANELI, R.S.; FONTANELI, R.S.; SANTOS, H.P. et al. Rendimento e valor nutritivo de cereais de inverno duplo propósito: forragem verde e silagem ou grãos. Revista Brasileira de Zootecnia, v.38, n.11, p.2116-2120, 2009.

HAIGH, P.M; Effluent production from grass silages treated with additives and made in large-scale bunker silos. Grass and Forage Science, v.54, n.3, p.208-218, 1999.

HALL, M.B. Neutral detergent-soluble carbohydrates nutritional relevance and analysis. Gainesville: University of Florida/Institute of Food and Agricultural Sciences, 2000. $42 \mathrm{p}$.

HARRISON, J.H; BLAUWIEKEL, R.; STOKES, M.R. Fermentation and utilization of grass silage. Journal of Dairy Science, v.77, n.10, p.3209-3235, 1994.

LAVEZZO, W.; ANDRADE, J.B. Conservação de forragens: feno e silagem. In: SIMPÓSIO BRASILEIRO DE FORRAGENS E PASTAGENS, 1994, Campinas. Anais... Campinas: Colégio Brasileiro de Nutrição Animal, 1994. p.105-166.

LICITRA, G.; HERNANDEZ, T.M.; VAN SOEST, P.J. Standardization of procedures for nitrogen fractionation of ruminants feeds. Animal Feed Science and Technology, v.57, p.347-358, 1996.

MAYLAND, H.F., GRUNES, D.L.; LAZAR, V.A. Grass tetany hazard of cereal forages based upon chemical composition. Agronomy Journal, v.68, p.665-67, 1976.

McDONALD, P.; HENDERSON, A.R.; HERON, S. The biochemistry of silage. Marlow: Chalcombe, 1991. 340p.
MCDOWELL, L.R.; VALLE, G. Major Minerals in Forages. In: GIVENS, D.I.; OWEN, E.; AXFORD, R.F.E. (Eds.) Forage evaluation in ruminant nutrition. Wallington, 2006. 480p.

MINSON, D.J. Forage in ruminant nutrition. San Diego: Academic Press, 1990. 483p.

MÜHLBACH, P.R.F. Silagem: produção com controle de perdas. In: LOBATTO, J.F.P.; BARCELLOS, J.J.; KESSLER. A.M. et al. (Eds.) Produção de bovinos de corte. Porto Alegre: Editora PUC/RS, 1999. p.97-120.

NATIONAL RESEARCH COUNCIL - NRC. Nutrient requirements of dairy cattle. 7.ed. Washington D.C.: National Academy Press, 2001. 381p.

PRIMAVESI, A.C.; PRIMAVESI, O.; CHINELLATO, A. et al. Indicadores de determinação de cortes de cultivares de aveia forrageira. Scientia Agrícola, v.58, n.1, p.79-89, 2001.

TEDESCO, M.J.; GIANELLO, C.; BISSANI, C.A. et al. Análise de solo, plantas e outros materiais. 2.ed. Porto Alegre: UFRGS, 1995. 174p. (Boletim, 5).

TILLEY, J.M.A.; TERRY, R.A. A two-stage technique for the in vitro digestion of forage crops. Journal British of Grassland Society, v.18, p.104-111, 1963.

VALADARES FILHO, S.C.; ROCHA FILHO, V.R.; CAPELLE, E.R. Tabelas brasileiras de composição de alimentos para bovinos - cqbal 2.0. Viçosa, MG: UFV, DZO, DPI, 2002. 297p.

VAN SOEST, P.J.; ROBERTSON, J.B.; LEWIS, B.A. Methods for dietary, fiber neutral detergent fiber and nonstarch polysaccharides in relation to animal nutririon. Journal of Dairy Science, v.74, n.10, p.3583-3597, 1991.

ZEOULA, L.M.; CALDAS NETO, S.F.; PRADO, I.N. et al. Caracterização das frações dos carboidratos de alguns alimentos segundo o CNCPS. In: REUNIÃO ANUAL DA SOCIEDADE BRASILEIRA DE ZOOTECNIA, 40., 2003, Santa Maria. Anais... Santa Maria: SBZ, [2003]. (CD-ROM). 